\title{
Estimation activity and partial purification of Ceruloplasmin from sera of patients with chronic renal Failure and healthy subjects
}

\author{
Israa Ghassan Zainal \\ Department of Chemistry, College of Science, Al-Mustansiryh University, Baghdad, Iraq
}

Email address:

israaz@yahoo.com

\section{To cite this article:}

Israa Ghassan Zainal. Estimation Activity and Partial Purification of Ceruloplasmin from Sera of Patients with Chronic Renal Failure and Healthy Subjects. Advances in Biochemistry. Vol. 2, No. 6, 2014, pp. 90-94. doi: 10.11648/j.ab.20140206.12

\begin{abstract}
CeruloplasminCP (EC1.16.3.1) activity has been assayed in (32) serum samples of patients with Chronic Renal Failure CRF, and (32) serum samples of healthy individuals without any clinically detectable diseases have been used as control group. The aim of this study is to measure $\mathrm{CP}$ activity and partially purifying the enzyme from sera of patients with $\mathrm{CRF}$ and healthy individuals. The results of this study revealed that $\mathrm{CP}$ activity of patient's serum shows a highly significant decrease $(p<0.05)$ compared to that of the healthy individuals. Ceruloplasmin enzyme was partially purified from the serum of patient with CRF and and healthy individual by three steps which operates throughout under mild conditions $4^{\circ}$, acetate buffer (pH 6.8): First step including the use of ammonium sulfate precipitation, second step utilize dialysis with acetate buffer, while the third step consists of gel-filtration on Sephacryl S200 $(27 \times 1.6 \mathrm{~cm})$. Insufficiently purified ceruloplasmin fractions obtained at various stages are diluted to the appropriate ionic strength and re-utilized. Two proteinous components had been isolated by gel filtration chromatography from the supernatant produced by ammonium sulfate. According to Poly Acryl Amide Electrophoresis PAGE appear two bands by protein staining. Abbreviation: ceruloplasmin, chronic renal failure, ammonium sulfate, dialysis, electrophoresis, gel filtration.
\end{abstract}

Keywords: Ceruloplasmin, Chronic Renal Failure, Ammonium Sulfate, Dialysis, Electrophoresis, Gel Filtration

\section{Introduction}

Chronic renal failure (CRF) is a major public health problem with increasing incidence ${ }^{(1)}$.Chronic renal failure characterized by decline in glomerular filtration perturbation of extracellular fluid volume, electrolytes and acid base homeostasis and retention of nitrogenous waste from protein catabolism ${ }^{(2)}$.However, data on the burden of CRF in the Arab world remains poorly understood ${ }^{(3)}$.The primary cause leading to renal failure is a free radical medicated injury to the endothelial cells in the outer medulla. ${ }^{(4)}$. Peroxidation of polyunsaturated fatty acids in the cell membrane generate free radicals and subsequent generation of further unstable radicals leading to a chain of events. This attack makes cell membrane leaky and the functions of absorption and secretion are lost that finally leads to cell death ${ }^{(5)}$.The balance between pro oxidant and antioxidant capacity is shifted towards an increased oxidative stress in CRF patients ${ }^{(6)}$.Chronic renal failure was described as a state of oxidant/antioxidant imbalance ${ }^{(7)}$.There is increasing evidence about the presence of oxidative stress in CRF patients; this seems to be due to multiple factors including an increase in the production of agents from oxidative metabolism (oxygen- derived substances generated by activated leucocytes, transition metal compounds, and other toxins of different molecular weight), and a decrease in antioxidant defenses. Oxidative stress generated in a physiologic or pathologic way and harms the cellular constituents including membrane lipids, proteins, and $\mathrm{DNA}^{(8)}$ and exert cytotoxic effects on cellular components ${ }^{(9)}$. Protein molecules may be attacked whenever free radicals are generated $^{(10,11)}$. Ceruloplasmin CP (EC 1.16.3.1) is acute phase reactant protein with a molecular weight of approximately $132 \mathrm{kDa}$, circulates in plasma as a major copper ion transporter and accounts for more than $95 \%$ of the copper found in serum ${ }^{(12)}$. It is one group of serum protein which rises after any form of tissue injury ${ }^{(13)}$. Ceruloplasmin has diverse functions as a copper transporter, it is essential 
for iron homeostasis, is involved in tissue angiogenesis and blood coagulation $^{(14)}$. It has been reported that CP catalyzed the oxidation of $\mathrm{Fe}$ (II) to $\mathrm{Fe}$ (III), the catalytic cycle involving four of the six copper atoms associated with $\mathrm{CP}$ that employ dioxygen as the terminal electron acceptor without the intermediacy of a partially reduced oxygen species such as $\mathrm{O}_{2}^{-}$or $\mathrm{H}_{2} \mathrm{O}_{2}{ }^{(15)}$. This oxidase activity increases during inflammation, infection, and injury which suggests that serum CP possibly acts as an antioxidant and as an acute phase protein ${ }^{(16)}$. Ceruloplasmin may function also as an antioxidant in two different ways: free copper and iron ions are powerful catalysts of free radical damage, by binding copper; $\mathrm{CP}$ prevents free copper ions from catalyzing oxidative damage ${ }^{(17)}$. It has been implied that substantial $\mathrm{CP}$ inactivation may occur and free copper ions may be released during exposure to oxidative stress ${ }^{(18,19)}$. Therefore, damaged $\mathrm{CP}$ may cause the augmentation of free radical-mediated damage to other macromolecules upon exposure to oxidative stress ${ }^{(20)}$. The aim of this study is to measure CP activity and partially purifying the enzyme from sera of patients with renal failure and healthy individuals.

\section{Materials and Methods}

\subsection{Chemicals}

All laboratory chemicals and reagents were of analar grade: Tris (Hydroxy methyl) amino methane was obtained from Fluka- Switzerland company, and bovine serum albumin(BSA)from Sigma- USA company.

\subsection{Specimens}

Thirty two serum samples collected from healthy individuals (20) men and (12) women without any detectable diseases, age range between (20-70) years, and (32) patients serum with chronic renal failure (17) men and from (15) women, age range between (18-75) years. The disease were diagnosed by specialist doctors in AL-emamain hospital, Baghdad, Iraq.

About $10 \mathrm{ml}$ of vinous blood was collected in plane tube using plastic disposable syringes and left for 20 minutes at room temperature $\left(25^{\circ} \mathrm{C}\right)$. After coagulation, sera were separated by centrifugation at $1500 \mathrm{xg}$ for 15 minutes. Sera were frozen in $-20^{\circ} \mathrm{C}$ freezer until analysis.

\subsection{Ceruloplasmin Activity Assay}

The enzymatic assay of ceruloplasmin oxidase activity was carried out using the modified Rice method ${ }^{(21)}$ by using p-phenylene diamine- $2 \mathrm{HCl}$ as a substrate. The $\mathrm{CP}$ activity was expressed in term of $(\mathrm{U} / \mathrm{L})$.

\subsection{Total Serum Protein}

Serum protein concentration was determined by Lowry et. al. method ${ }^{(22)}$, by using bovine serum albumin (BSA) as a standard protein.

\subsection{Purification Procedures}

Serum was treated with $\left(\mathrm{NH}_{4}\right)_{2} \mathrm{SO}_{4}$ as mentioned by Dixon and Webb ${ }^{(23)}$ in two steps. First, solid $\left(\mathrm{NH}_{4}\right)_{2} \mathrm{SO}_{4}$ was added gradually to the serum to $60 \%$ saturation in an ice bath, then the mixture was stirred for $15 \mathrm{~min}$, and left at $4{ }^{\circ} \mathrm{C}$ for $60 \mathrm{~min}$ The precipitate was removed by centrifugation. In the second step, the supernatant was treated with solid $\left(\mathrm{NH}_{4}\right)_{2} \mathrm{SO}_{4}$ to $80 \%$ saturation, stirred for $15 \mathrm{~min}$, and left at $4{ }^{\circ} \mathrm{C}$ for $60 \mathrm{~min}$. The supernatant with ceruloplasmin activity was centrifuged at $2000 \mathrm{xg}$ for $30 \mathrm{~min}$ and dialyzed at $4{ }^{\circ} \mathrm{C}$ against the acetate buffer(0.4M, pH= 5.2) overnight. Gel chromatography on Sephacryl S200 was carried out in acetate buffer $(0.4 \mathrm{M}, \mathrm{pH}=$ $5.2)$ on a column of dimensions $(26 \times 1.6 \mathrm{~cm})$. The fraction with ceruloplasmin activity was dialyzed against sucrose.

\section{Electrophoresis}

Polyacrylamide gel electrophoresis (PAGE) was performed as described by Laemmli ${ }^{(24)}$ using a $12 \%$ separating gel, $3 \%$ stacking gel, but without sodium dodecyl sulfate and mercapto ethanol. The protein bands were localized with Coomassie brilliant blue R250.. In order to locate the position of CP bands, polyacrylamide gel was cut to two pieces: the first was stained using staining protein method. They were aligned with the second unstained portion of the gel, which is used to determined CP activity using PPD (P-phenylenediamine) as a substrate ${ }^{(21)}$.

\section{Results}

Table 1 reports data of the Ceruloplasmin activity and protein concentration in the sera of CRF patients compared with the healthy individuals:

Table (1). Ceruloplasmin activity and protein concentration in the sera of CRF patients and healthy individuals.

\begin{tabular}{llll}
\hline Parameters & Chronic Renal Failure Patients $(\mathbf{n}=\mathbf{3 2})$ mean \pm SD & Healthy Individuals $(\mathbf{n}=\mathbf{3 2})$ mean \pm SD & P \\
\hline Ceruloplasmin U/L & $74.76 \pm 11.3$ & $92.35 \pm 20.9$ & $<0.05$ \\
Protein g/dl & $5.66 \pm 0.7$ & $7.59 \pm 0.41$ & $<0.05$ \\
\hline
\end{tabular}

From table 1 the results above indicated that ceruloplasmin activity and protein concentration were decreased in patients with CRF compared to healthy individuals.

The results of purification experiments are summarized in tables 2 and 3 for CRF patients and healthy individuals, respectively. After each purification step, the protein content and the enzyme activity were determined. 
Table (2). Purification of ceruloplasmin from human serum CRF patients.

\begin{tabular}{|c|c|c|c|c|c|c|}
\hline & Volume/ml & $\begin{array}{l}\text { Total protein } \\
\text { mg }\end{array}$ & $\begin{array}{l}\text { Total activity } \\
\text { U }\end{array}$ & $\begin{array}{l}\text { Specific activity } \\
\text { U/ mg }\end{array}$ & Yield/\% & $\begin{array}{l}\text { Purification } \\
\text { (fold) }\end{array}$ \\
\hline Crude serum & $3 \mathrm{ml}$ & 129 & 239.34 & 0.618 & & \\
\hline Ammonium sulfate & $2 \mathrm{ml}$ & 61.2 & 57.9 & 0.946 & 72.6 & 1.5 \\
\hline Dialysis & $\begin{array}{l}1.5 \mathrm{ml} \\
\text { Gel filtration }\end{array}$ & 30.9 & 38.03 & 1.23 & 47.7 & 1.2 \\
\hline Fraction 1 & $12 \mathrm{ml}$ & 3.24 & 22.2 & 6.852 & 27.8 & 11.1 \\
\hline Fraction 2 & $8 \mathrm{ml}$ & 0.8 & 22.7 & 28.38 & 28.5 & 45.9 \\
\hline
\end{tabular}

a ammonium sulfate supernatant, ${ }^{b}$ ammonium sulfate pellet.

Table (3). Purification of ceruloplasmin from human serum healthy subjects.

\begin{tabular}{|c|c|c|c|c|c|c|}
\hline & Volume/ml & $\begin{array}{l}\text { Total protein } \\
\text { mg }\end{array}$ & $\begin{array}{l}\text { Total activity } \\
\text { U }\end{array}$ & $\begin{array}{l}\text { Specific activity } \\
\text { U/ mg }\end{array}$ & Yield $/ \%$ & $\begin{array}{l}\text { Purification } \\
\text { (fold) }\end{array}$ \\
\hline Crude serum & $3 \mathrm{ml}$ & 174 & 106.3 & 0.611 & & \\
\hline Ammonium sulfate & $2 \mathrm{ml}$ & 96 & 79.92 & 0.833 & $\overline{75.2}$ & 1.4 \\
\hline $\begin{array}{l}\text { Dialysis } \\
\text { Gel filtration }\end{array}$ & $1.5 \mathrm{ml}$ & 46.05 & 53.54 & 1.163 & 50.4 & 1.9 \\
\hline Fraction 1 & $12 \mathrm{ml}$ & 7.8 & 32.4 & 4.154 & 30.5 & 6.8 \\
\hline Fraction 2 & $8 \mathrm{ml}$ & 3.2 & 35.7 & 11.2 & 33.6 & 18.3 \\
\hline
\end{tabular}

${ }^{\mathrm{a}}$ ammonium sulfate supernatant, ${ }^{\mathrm{b}}$ ammonium sulfate pellet.

Results of the chromatographic procedure were shown in figures $1 \& 2$ for CRF patients and healthy individuals, respectively.

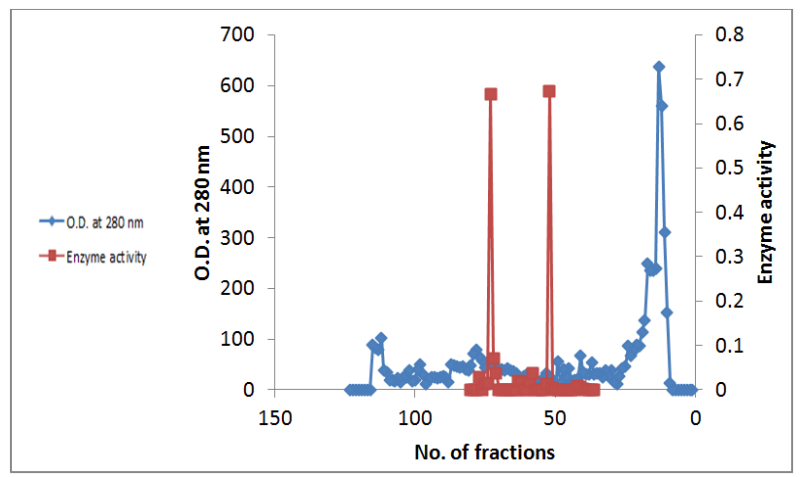

Figure (1). Gel chromatography on a Sephacryl S200 column; protein concentration (blue), ceruloplasmin activity in the sera of human patients (red).

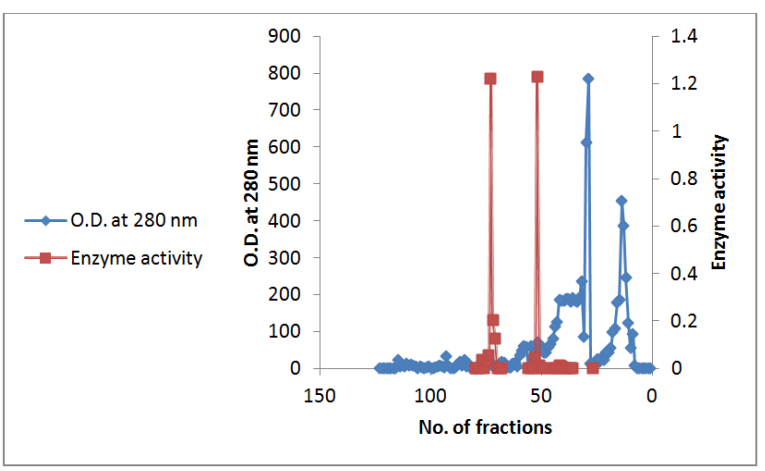

Figure (2). Gel chromatography on a Sephacryl S200 column; protein concentration (blue), ceruloplasmin activity in the sera of human control(red).

According to the present results, ammonium sulphate precipitation to $60-80 \%$ saturation eliminated $(27.4 \%$ for patient serum and $24.8 \%$ for healthy individual serum) of the ballast proteins,. From figures $1 \& 2$ its clear that there were 2 peaks for enzyme after passing the dialysis sample in thecolumn of gel chromatography on Sephacryl S 200, 72.2\% $\& 69.5 \%$ of the ballast proteins for fraction 1 (patient \& healthy individual) and $71.5 \%$ patients and $66.4 \%$ healthy individual of the ballast proteins for fraction 2 were discarded with a loss of ceruloplasmin activity of about $70 \%$ for fractions $1 \& 2$ for patients and healthy individuals. Results of this chromatographic procedures were shown in Figures (1 and 2).

The total purification achieved by the procedure outlined in table 1 was (11.1 fold with yield $27.8 \%$ fraction $1 \& 45.9$ fold with yield $28.5 \%$ fraction 2 ) for patients and (6.8 fold with yield $30.5 \%$ fraction 1 \& 18.3 fold with yield $33.6 \%$ fraction 2) for healthy individuals. The specific activity of the purified enzyme for each fraction increased after using gel filtration steps as clear in tables $1 \& 2$. The degree of purification of the CP enzyme in every purification step was examined by PAGE as shown in Figure 3.

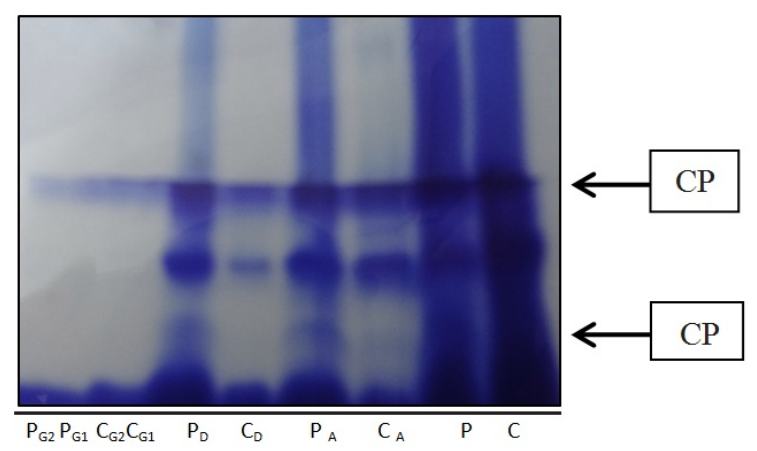

Figure (3). Protein staining of conventional - PAGE $12 \%$ profile of partially purified and crude sera CP. $C=$ control, $P=$ patient, $C_{A}=$ control serum using ammonium sulfate, $P_{A}=$ patient serum using ammonium sulfate, $C_{D}=$ control serum using dialysis, $P_{D}=$ patient serum using dialysis, $C_{G 1}=$ control serum using gel filtration fraction $1, C_{G 2}=$ control serum using gel filtration fraction2, $P_{G I}=$ patients serum using gel filtration fraction 1 and $P_{G 2}=$ patients serum using gel filtration fraction 2 . 


\section{Discussion}

This study is aimed to study the level of CP and attempt to partially purify enzyme in the sera of patients with CRF compare to healthy individuals. Fragmentation of $\mathrm{CP}$ during purification and storage has hampered studies of its structure, but it has been shown to be a $132-\mathrm{kDa}$ monomer (26). Ceruloplasmin has aroused interest for many years due to its redox potential displaying oxidant or antioxidant properties according to environmental conditions (27). The purification of $\mathrm{Cp}$ from various plasma sources (human, camel, bovine, horse, rat, chicken, goose, and rat) was described in the literatures $(28,29,30,31,32,33,34,35)$. The present study describes a simple human $\mathrm{Cp}$ partial purification protocol including ammonium sulfate, dialysis and gel filtration with sephacryl -S200 to the sera of CRF patient and healthy subject. Ammonium sulfate was used to precipitate the crude proteins; previous work shows that ammonium sulfate at 60 $\%$ saturation level efficiently removes high molecular weight proteins (36). In one hand, increase in the saturation level of the ammonium sulfate increases the quantity of the protein precipitated from the clarified homogenate, because some proteins with few hydrophilic regions precipitate at lower ammonium sulfate saturation level and some other proteins with more hydrophilic region precipitate higher saturation of ammonium sulfate $(37,38)$.In this study ammonium sulfate saturation level between $(60-80) \%$.This is supported by the previous report that ammonium sulfate saturation levels for more than $60 \%$ reduce substantial high molecular weight proteins and majority of the hydrophobic protein $(36,39)$.Protein precipitation by ammonium sulfate is the high - throughput method to concentrate proteins compared to other process alternatives such as ultrafiltration because proteins in mixture can be separated from one another efficiently based on their relative hydrophilicity by gradually increasing the concentration of ammonium sulfate (40). Ahmed and AL-Helaly (41) were isolated CP from human serum using polyethylene glycol (4000). After gel chromatography on Sephacryl S200 column, two fractions were appeared in patient $(27.8 \& 28.5) \% \&$ in healthy individual $(30.5 \& 33.6) \%$ of the ballast proteins were discarded. Results of this chromatographic procedure were shown in figures $(1 \& 2)$ and tables $(1 \& 2)$. The total purification achieved by the procedure outlined in tables (1\&2) were (11.1 \& 45.9) fold for patient and (6.8\&18.3) fold for healthy individual over the first soluble fraction. The specific activity of the purified enzyme was (6.852\&28.38) $\mathrm{U} / \mathrm{mg}$ for patients fragments and (4.154\&11.2) U/mg for healthy individual fractions, in literature specific activity were $(6.8 \& 13.9) \mathrm{U} / \mathrm{min} / \mathrm{mg}$ for healthy individual only (41). Ahmed and AL-Helaly (41) had been isolated two proteinous components by gel filtration chromatography from the precipitate produced by polyethylene glycol (4000). It was found that only the second peak had a high activity for CP. Raju KS (42) isolated two peaks for CP enzyme from human serum. Gaumnitz(43), purified CP by Chromatography from the plasma of patient with Wilson's disease together with a purification of CP from plasma of normal individual.

The degree of purification of the CP enzyme in every purification step was examined by PAGE as shown in figure 3.Staining for protein by Coomassie brilliant blue indicated that there were two bands for CP enzyme in human serum (patient \& healthy individual), as clear from figure 3 the second band is not clear after purification with gel filtration.To our knowledge this is the first work that partially purified the CP enzyme from human patients with CRF

\section{References}

[1] M. P. Kao, D. S. Ang, A. Pall, and A. D. Struthers. Oxidative stress in renal dysfunction: mechanisms, clinical sequelae and therapeutic options, Journal of human hypertension. 2010; vol. 24, no. 1, pp. 1-8.

[2] Meerashivashekar, W. Ebenezer William, R. Revathi, Padmanabhan. Effect of oxidative stress in pre and post hemodialysis in chronic renal failure. 2012;3(1): 1335-1337.

[3] Abulkareem, O Alsuwadi, Youssef M K Faraz, Abdulla A Alsayyan, Dujanah Mousa, Fayez Alhejalli, Ajay k Singh et al Epidemiology of chronic kidney disease in the Kingdom of Saudi Arabia (SEEK-Saudi investigators) - A pilot study. Saudi Journal of Kidney disease and Transplantation. 2010;21 (6): 1066-1072.

[4] Krachler M, Scharfetter H, Wirnsberger G.kinetics of the metal cations magnesium, calcium, copper, zinc, strontium, barium and lead in chronic hemodialysis patients. Clin Nephrol.2000; 54: 35-44.

[5] Taylor JE, Scott N, Bridges A, Henderson IS, Stewart WK, Belch JJ. Lipid peroxidation and anti oxidants in continous ambulatory dialysis patients. Perit.Dial.Int.1992; 12(2):252256.

[6] Dr.Meerashivashekar* Dr. W.Ebenezer William, R.Revathi, Dr. Padmanabhan. Effect of oxidative stress in pre and post hemodialysis in chronic renal failure patients. Int J Biol Med Res.2012;3(1): 1335-1337.

[7] Mircescu G, Capuşă C, Stoian I, Vârgolici B, Barbulescu C, Ursea N. Global assessment of serum antioxidant status in hemodialysis patients. J Nephrol.2005; 18(5):599-605, SepOct.

[8] Gonzalez Rico, M., Puchades, M.J., Garcia Ramon, R., Saez, G., Tormos, M.C., Miguel, A. Effect of hemodialysis therapy on oxidative stress in patients with chronic renal failure Nefrologia.2006;26(2): 218-225.

[9] Samouilidou E, Grapsa E. Effect of dialysis on plasma total antioxidant capacity and lipid peroxidation products in patients with end stage renal failure. Blood purify.2003;21 (3): $209-212$.

[10] Davies KJA. Protein damage and degradation by oxygen free radicals. II Modification of amino acids. J Biol Chem.1987; 262: 9902-9907.

[11] Davies KJA. Protein damage and degradation by oxygen free radicals. IV Degradation of denatured proteins. J Biol Chem.1987;262: 9914-9920. 
[12] Goldstein, I. M., Kaplan, H. B., Edelson, H. S. and Weissmann, G. Ceruloplasmin. A scavenger of superoxide anion radicals. J. Biol. Chem.1979; 254, 4040-4045.

[13] CousinsRJ. Absorption, transport, and hepaticmetabolism of copper and zink: special reference to metallothionein and ceruloplasmine . Physiol. Rev.1985; 65(2):238-309.

[14] Giurgea N, Constantinescu MI, Stanciu R, Suciu S, Muresan A. Ceruloplasmin - acute-phase reactant or endogenous antioxidant? The case of cardiovascular disease. Med Sci Monit.2005; 11:RA48-51.

[15] Ryden, L. Ceruloplasmin: in Copper proteins and copper enzymes, Lantie, R. (ed), CRC, Boca Raton, USA.1984; pp. 37-100.

[16] Fleming, R. E., Whitman, I. P. and Gitlin, J. D. Induction of ceruloplasmin gene expression in rat lung during inflammation and hyperoxia. Am. J. Physiol.1991; 260, 68-74.

[17] Johnson MA, Fischer JG, Kays SE. Is copper an antioxidant nutrient? Crit Rev Food Sci Nutr.1992; 32(1):1-31.

[18] Swain, J. A., Darley-Usmar, V. and Gutteridge, J. M. Peroxynitrite releases copper from caeruloplasmin: implications for atherosclerosis. FEBS Lett.1994; 342, 49-53.

[19] Choi, S. Y., Kwon, H. Y., Kwon, O. B., Eum, W. S. and Kang, J. H. Fragmentation of human ceruloplasmin induced by hydrogen peroxide. Biochimie.2000; 82, 175-180.

[20] Jung Hoon Kang. Oxidative Modification of Human Ceruloplasmin by Methylglyoxal: Journal of Biochemistry and Molecular Biology.2006; Vol. 39, No. 3, pp. 335-338 May .

[21] Rice E.W.; Ceruloplasmin assy in serum: Standarization of CP activity in terms of international enzyme unit "Standard methods of cliical chemistry, Ed.Siligso, New York, Academic press.1962; pp:4.

[22] Lowery H.,Rosebough J.,and Randall j. Protein measurement with the folin phenol.Biol.Chem.1951;193: 265-275.

[23] Dixon M.,Webb E. Enzymes, $2^{\text {nd }}$ ed.,Academic press.Unc.New York.1964.

[24] Amersham Biosciences: Protien elcetrophoresis technical Manual. Hand book, U.S.A., 1999.

[25] Ehrenwald $E^{1}$, Fox PL. Isolation of nonlabile human ceruloplasmin by chromatographic removal of a plasma metalloproteinase.Arch Biochem Biophys.1994; Mar;309(2):392-5.

[26] Ferdinand Kouoh E.,Miryana R., Michel P.,Jacques D.,Sami C.,Thierry B.,Jean-Pierre C.,Jean-Lue B. and Nicole C. Purification Of Human Ceruloplasmin As a By - Product Of C1 Inhibitor. Biol.Pharm.Bull.2000; 23(12):1406-1409.

[27] Linder, M. C. and Moor, J. R. Plasma ceruloplasmin. Evidence for its presence in and uptake by heart and other organs of the rat. Biochim. Biophys. Acta.1977; 499, 329-336.

[28] Noyer, M.; Dwulet, F.E.; Hao, Y.L., and Putnam, F.W.
Purification and Characterization of Undegraded Human Ceruloplasmin. Anal. Biochem.1980;102: pp.450-458.

[29] Essamadi, A. K., Bengoumi, M., Zaoui, D., Faye, B., Bellenchi, G. C., Musci, G., and Calabrese, L. Purification and partial characterization of camel (Camelus Dromedarius) ceruloplasmin. Comp. Biochem. Physiol. B: Biochem. Mol. Biol.2002;131, 509-517.

[30] Calabrese, L., Malatesta, F., and Barra, D. Purification and properties of bovine caeruloplasmin. Biochem. J.1981;199, $667-673$

[31] Calabrese, L., Carbonaro, M., and Musci, G., Chicken. Ceruloplasmin. Evidence in support of a trinuclear cluster involving type 2 and 3 copper centers. J. Biol. Chem.1988; 263, 6480-6483.

[32] Hilewicz-Grabska, M., Zgirski, A., Krajewski, T., and Plonka, A. Purification and partial characterization of goose ceruloplasmin. Arch. Biochem. Biophys.1988; 260, 18-27.

[33] Okumura, M., Fujinaga, T., Yamashita, K., Tsunoda, N., and Mizuno, S. Isolation, characterization, and quantitative analysis of ceruloplasmin from horses. Am. J. Vet. Res.1991; $52,1979-1985$.

[34] Ehrenwald, E. and Fox, P. L. Isolation of nonlabile human ceruloplasmin by chromatographic removal of a plasma metalloproteinase. Arch. Biochem. Biophys.1994;309, 392395.

[35] Akita E.M.and Nakai S. Immunoglobulin from egg youlk : Isolation and Purification .Food Scince.1992; 57,629-634.

[36] Mirica KA, Lockett MR, Snyder PW, Shapiro ND, Mack ET, Nam $\mathrm{S}$ and Whitesides GM. Selective precipitation and purification of monovalent proteins using polyvalent ligands and ammonium sulfate.Bioconjug.Chem.2012;23,293-299.

[37] Ko ky and Ahn DU. Preparation of immunoglobulin Y from egg yolk using ammonium sulfate precipitation and ion exchange chromatochraphy . Poult Sci.2007; 86,400-407.

[38] Bortolato M,Besson F and Roux B. Role of metal ions on the secondary and quaternary structure of alkaline phosphatase from bovine intestinal mucosa .Proteins Struct Funct Genet.1999; 37:310-318.

[39] Moore PA and Kery V. High throughput protein concentration and buffer exchange comparison of ultrafiltration and ammonium sulfate precipitation. Methods Mol Biol.2009; 498,309-314.

[40] Tariq YA and Luay AA. Partial Separation and Some Kinetic Studies of Ceruloplasmin in Human Serum. J. Raf. Sci.2009; Vol. 20, No.1, pp 47- 60.

[41] Raju KS. Isolation and characterization of copper-binding sites of human ceruloplasmin. Mol Cell Biochem.1983; $56(1): 81-8$.

[42] Neil A. Holtzman, Michael A. Naughton, Frank L. Iber, and Bonnie M. Gaumnitz. Ceruloplasmin in Wilson's Disease. Journal of Clinical Investigation.1967; Vol. 46, No. 6. 